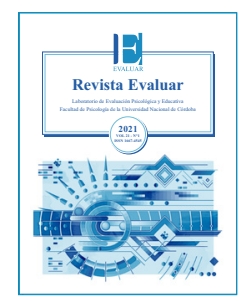

\title{
Measurement Invariance of the New Sexual Satisfaction Scale short form
}

\section{Invarianza de la Nueva Escala de Satisfacción Sexual versión corta}

\author{
Virginia Flores-Perez ${ }^{1}$, Esteban Jaime Camacho-Ruiz ${ }^{1}{ }^{*}$, María del Consuelo \\ Escoto-Ponce de León ${ }^{2}$, Brenda Sarahi Cervantes-Luna ${ }^{2}$, Manuel Leonardo \\ Ibarra-Espinosa ${ }^{1}$ \\ 1 - Centro Universitario UAEM Nezahualcóyotl, Universidad Autónoma del Estado de México, Nezahualcóyotl, México. \\ 2 - Centro Universitario UAEM Ecatepec, Universidad Autónoma del Estado de México, Ecatepec, México.
}

Introduction Method

Results

Discussion

References

Recibido: 30/09/2020 Revisado: 17/11/2020 Aceptado: 08/12/2020

\begin{abstract}
The objective was to assess the incremental validity, internal consistency and temporal stability of the New Sexual Satisfaction Scale short version (NSSS-S) in Spanish-speaking Latino adults. The sample included 401 university students (232 women and 169 men), sexually active, 18 to 38 years old $(\mathrm{M}=20.83 ; \mathrm{SD}=2.66)$. A subsample of 76 participants answered the scale four weeks after the first application. Confirmatory factor analysis (CFA) identified a two-factor structure. The invariance analysis with multigroup confirmatory factor analysis (MGCFA) confirmed the invariance by sex of the scale. The internal consistency reliability of the scale and its subscales was excellent for both men and women $(\omega=.89-.95)$ and the temporal stability, four weeks after the first application, was adequate $(r=.74 ; \mathrm{ICC}=.85)$. Finally, men scored higher in overall sexual satisfaction and the Ego-Centered subscale, but not in the Partner -and Sexual Activity-Centered subscale, as compared to women. To conclude, the NSSS-S is a psychometrically appropriate scale to measure sexual satisfaction in Spanish-speaking Latino adults.
\end{abstract}

Keywords: measurement invariance, factorial validity, confirmatory factor analysis, sexual satisfaction, university students
Resumen

El objetivo fue evaluar la validez incremental, la consistencia interna y la estabilidad temporal de la Nueva Escala de Satisfacción Sexual versión corta. La muestra incluyó 401 universitarios (232 mujeres y 169 hombres), sexualmente activos, de 18 a 38 años de edad $(\mathrm{M}=20.83$; $\mathrm{DE}=2.66$ ). Una submuestra de 76 participantes respondió la escala cuatro semanas después de la primera aplicación. El análisis factorial confirmatorio identificó una estructura de dos factores. El análisis de invarianza, usando MGCFA confirmó la invarianza por sexo de la escala. La consistencia interna de la escala y sus subescalas fue excelente, tanto para hombres como para mujeres $(\omega=.89-.95)$ y la estabilidad temporal, cuatro semanas después de la primera aplicación, fue adecuada $(r=.74 ; \mathrm{ICC}=.85)$. Finalmente, los hombres puntuaron más alto en satisfacción sexual global y en Ego-Centered, pero no en Partner -and Sexual Activity-Centered, en comparación con las mujeres. La NSSS-S es una medida de satisfacción sexual psicométricamente apropiada para la población hispano-latina.

Palabras clave: medición de invarianza, validez factorial, análisis factorial confirmatorio, satisfacción sexual, universitarios

\footnotetext{
Author's note

The first author thanks the National Council of Science and Technology (CONACYT) for granting scholarship 701590 for the completion of the master's studies in Sociology of Health.

*Correspondence to: Esteban Camacho Ruiz. Address: Av. Bordo de Xochiaca, Col. Benito Juárez, Nezahualcóyotl, Estado de México, México. C.P. 57000. Telephone: (52) 55-51126372 ext.7912. E-mail: jaime_camacho_ruiz@hotmail.com

How to cite: Flores-Perez, V., Camacho-Ruiz, E. J., Escoto-Ponce de León, M del C., Cervantes-Luna, B. S., \& Ibarra-Espinosa, M. L. (2021). Measurement invariance of the New Sexual Satisfaction Scale short form. Revista Evaluar, 21(1), 94-103. Recuperado de https://revistas.unc.edu.ar/index.php/revaluar
} 


\section{Introduction}

Sexual satisfaction (SS), the last phase of the human sexual response (Carrobles \& Sanz-Yaque, 1991) refers to the subjective assessment of liking or disliking that people make about their sexual relationships and includes the pleasant sensations derived from the physical act that are related to the emotional satisfaction of the individual in order to find confidence and self-confidence (Ahumada, Luttges, Molina, \& Torres, 2014; Lawrance \& Byers, 1995). High levels of SS are associated with higher global quality of life and self-esteem, and less depression, anxiety, stress, physical health problems, and poor self-concept; furthermore, both, self-esteem and body image predict SS (for a review, see Sánchez-Fuentes, Santos-Iglesias, \& Sierra, 2014).

Several instruments have been developed to measure SS: The Index of Sexual Satisfaction (ISS; Hudson, Harrison, \& Crosscup, 1981), the Golombok-Rust Inventory of Sexual Satisfaction (GRISS; Rust \& Golombok, 1986), the Pinney Sexual Satisfaction Inventory (PSSI; Pinney, Gerrard, \& Denney, 1987), the Global Measure of Sexual Satisfaction (GMSEX; Lawrance \& Byers, 1995), the Sexual Satisfaction Scale for Women (SSS-W; Meston \& Trapnell, 2005), the Subjective Sexual Satisfaction Scale (ESSS; González-Rivera, Veray-Alicea, Santiago-Santos, Castro-Castro, \& Quiñones-Soto, 2017) and its short form (ESSS-B; González-Rivera \& Hernández-Gato, 2019), the Sexual Sensation Seeking Scale (Kalichman et al., 1994; Moral de la Rubia, 2018) and the New Sexual Satisfaction Scale (NSSS; Štulhofer, Buško, \& Brouillard, 2010).

The PSSI (Pinney et al., 1987) and the SSS-W (Meston \& Trapnell, 2005) are scales designed to assess SS for women only. The first evaluates the general SS and the SS with the partner; the second evaluates two relational domains (communication and compatibility) and three interpersonal domains (feelings of inner happiness, concern for relationship, and personal concern) of women's SS. The ISS (Hudson et al., 1981) is a one-dimensional scale that assesses the degree, severity, and magnitude of relationship problems in the sexual component. However, the ISS was built based on the clinical and personal experience of the author, so its construct validity is questionable. The GRISS (Rust \& Golombok, 1986) is a measure of the existence and severity of sexual dysfunctions (e.g., impotence, anorgasmia, premature ejaculation, and vaginismus), designed for heterosexual couples. The GMSEX (Lawrance \& Byers, 1995) evaluates the overall $\mathrm{SS}$; however, the scale is restricted in terms of variance, since the measurement is made from an item and its reliability is limited (Mark, Herbenick, Fortenberry, Sanders, \& Recee, 2014). The ESSS (González-Rivera et al., 2017) is a multidimensional scale that evaluates the perception of sexual life, negative feelings after sexual activity, perceived sexual performance, and the individual role during sexual intercourse. However, the ESSS focuses on the evaluation of the SS centered on the person.

The NSSS (Štulhofer et al., 2010) is a useful instrument to assess SS and is based on the theory of Bancroft, Loftus, and Long (2003) called three windows. The authors evaluated the scale in diverse samples: adults and young, men and women, heterosexual and different sexual orientation, clinical and community samples. The NSSS can be used for research in non-clinical settings.

Originally the NSSS (Štulhofer et al., 2010) included 20 items. The principal component analysis (PCA) with oblimin rotation derived two dimensions: The Ego-Centered subscale, devoted on personal experiences and sensations (e.g. quality and frequency of one's sensations, orgasms, and sexual excitement) and the Partner -and Sex- 
ual Activity-Centered subscale (e.g. trust, commitment and emotional closeness with a partner). The authors evaluated the internal consistency in two student samples, two community samples, and one sample of Croatian non-heterosexual adults, and reported Cronbach's alpha indices of $\geq .94$ for the full-scale and $\geq .90$ for both subscales and the short version.

In a later study, Štulhofer, Buško and Brouillard (2011) derived a short version (NSSS-S), which includes 12 Likert-type items $(1=$ Not at all satisfied to $5=$ Extremely satisfied). The PCA with oblimin rotation derived a factor that measures personal and partner sexual satisfaction, regardless of gender, sexual orientation, or marital status.

The factorial structure of the NSSS-S has been studied in different countries and languages: Canada and United States (Mark et al., 2014), United States and Croatia (Štulhofer et al., 2011), Portugal (Santos-Pechorro et al., 2016), Spain (Strizzi, Fernández-Agis, Alarcón-Rodríguez, \& Parrón-Carreño, 2016) and Germany (Hoy, Strauß, Kröger, \& Brenk-Franz, 2019). Previous studies have included participants from community sample, clinical sample, university students, and people with different sexual orientations, both men and women.

In general, studies have found that the NSSS-S has excellent internal consistency $(\alpha=.90$ - .96) and adequate test-retest temporal stability $(r=.72-.84$; Mark et al., 2014; Štulhofer et al., 2011). However, the results regarding factor validity are inconsistent. In this sense, some studies have found that the scale is one-dimensional (Hoy et al., 2019; Štulhofer et al., 2011), while others have identified two factors (Mark et al., 2014; Santos-Pechorro et al., 2016; Strizzi et al., 2016).

The NSSS-S was recently translated and adapted for adult women and men in Spain (Strizzi et al., 2016). The principal axis factoring extraction with promax rotation derived two factors. Confirmatory factor analysis (CFA) proved the existence of two factors. It should be noted that factor validity for the NSSS-S has not been evaluated in Spanish-speaking Latino adults. Furthermore, the invariance by sex for this scale has not been studied.

Table 1

Goodness of fit indices for the NSSS-S.

\begin{tabular}{|c|c|c|c|c|c|c|c|}
\hline Models & $\chi^{2} / \mathbf{S C F}$ & $d f$ & $p$ & $\begin{array}{l}\text { RMSEA } \\
\text { (CI) }\end{array}$ & SRMR & CFI & TLI \\
\hline $\begin{array}{l}\text { CFA unidimensional } \\
(\mathrm{n}=401)\end{array}$ & 162.137 & 54 & .0001 & $\begin{array}{c}.084 \\
(.072-.097)\end{array}$ & .040 & .934 & .919 \\
\hline $\begin{array}{l}\text { CFA bifactor } \\
(\mathrm{n}=401 ;[\mathrm{F} 1=\text { items } 1-6 ; \mathrm{F} 2 \\
=\text { items } 7-12])\end{array}$ & 143.921 & 53 & .0001 & $\begin{array}{c}.078 \\
(.066-.091)\end{array}$ & .038 & .944 & .930 \\
\hline $\begin{array}{l}\text { CFA bifactor re-specified } \\
(\mathrm{n}=401 ;[\mathrm{F} 1=\text { items } 1-6 ; \mathrm{F} 2 \\
=\text { items } 7-12])\end{array}$ & 112.255 & 52 & .0001 & $\begin{array}{c}.066 \\
(.053-.079)\end{array}$ & .033 & .961 & .950 \\
\hline
\end{tabular}

Note. $\chi^{2}=$ Chi square; SCF $=$ scaling correction factor for MLR; $d f=$ degrees of freedom; $p=$ significance; RMSEA $=$ root mean square error of approximation; $\mathrm{CI}=$ confidence interval; SRMR $=$ root mean square residual; $\mathrm{CFI}=\mathrm{comparative}$ fit index; TLI $=$ Tucker-Lewis index. 
Finally, previous studies have used Cronbach's alpha coefficient to assess the internal consistency of the scale. However, some authors have pointed out that the Cronbach's alpha coefficient has some limitations, for example, it is affected by the number of items, the number of response options, and the proportion of the variance (Domínguez-Lara \& Merino-Soto, 2015). Therefore, it has been suggested to include more adequate indices for calculating the internal consistency of scales of an ordinal nature. In this sense, this study aimed to evaluate two previously identified factorial models for the NSSS-S (Mark et al., 2014; Štulhofer et al., 2011), in Spanish-speaking Latino adults using CFA. It also aimed to assess the incremental validity, the internal consistency and the temporal stability of the scale using multi-group confirmatory factor analysis (MGCFA) and finally, to compare the SS between men and women.

\section{Methods \\ Participants}

The sample included 401 university students (232 female and 169 male), sexually active, from 18 to 38 years old $(\mathrm{M}=20.83$; $\mathrm{SD}=2.66)$ selected by non-probability convenience sampling, selected from two public universities in the municipality of Nezahualcoyotl, State of México. A subsample of 76 participants answered the scale four weeks after the first application.

\section{Instruments}

Sexual satisfaction. The NSSS-S (Štulhofer et al., 2011) was previously described. In the present study, we used the translated version, adapted by Strizzi et al. (2016).

Table 2

Invariance by sex.

\begin{tabular}{|c|c|c|c|c|c|c|c|c|c|}
\hline Models & $\chi^{2} / \mathrm{SCF}$ & $d f$ & $p$ & $\begin{array}{l}\text { RMSEA } \\
\text { (CI) }\end{array}$ & SRMR & CFI & TLI & $\begin{array}{c}\Delta \\
\text { RMSEA }\end{array}$ & $\begin{array}{c}\Delta \\
\text { CFI }\end{array}$ \\
\hline \multirow{2}{*}{\multicolumn{10}{|c|}{$\begin{array}{l}\text { MGCFA } \\
\text { By sex }(\mathrm{n}= \\
401)\end{array}$}} \\
\hline & & & & & & & & & \\
\hline $\begin{array}{l}\text { Females } \\
\text { re-specified } \\
(\mathrm{n}=232)\end{array}$ & 111.292 & 52 & .0001 & $\begin{array}{c}.086 \\
(.070-.104)\end{array}$ & .042 & .938 & .921 & & \\
\hline $\begin{array}{l}\text { Males re-spec- } \\
\text { ified } \\
(\mathrm{n}=169)\end{array}$ & 48.030 & 52 & .259 & $\begin{array}{c}.026 \\
(.000-.057)\end{array}$ & .032 & .993 & .991 & & \\
\hline $\begin{array}{l}\text { Configural } \\
\text { invariance }\end{array}$ & 162.792 & 104 & .0001 & $\begin{array}{c}.069 \\
(.055-.083)\end{array}$ & .038 & .958 & .947 & & \\
\hline $\begin{array}{l}\text { Metric } \\
\text { invariance }\end{array}$ & 169.167 & 114 & .0001 & $\begin{array}{c}.064 \\
(.050-.078)\end{array}$ & .043 & .960 & .954 & -.002 & .002 \\
\hline $\begin{array}{l}\text { Scalar } \\
\text { invariance }\end{array}$ & 182.330 & 124 & .0001 & $\begin{array}{c}.062 \\
(.049-.076)\end{array}$ & .044 & .959 & .956 & .007 & -.001 \\
\hline $\begin{array}{l}\text { Strict } \\
\text { invariance }\end{array}$ & 183.469 & 136 & .0001 & $\begin{array}{c}.057 \\
(.043-.070)\end{array}$ & .049 & .963 & .964 & .005 & .004 \\
\hline
\end{tabular}

Note. $\chi^{2}=$ Chi square; $\mathrm{SCF}=$ scaling correction factor for MLR; $d f=$ degrees of freedom; $p=$ significance; RMSEA $=$ root mean square error of approximation; $\mathrm{CI}=$ confidence interval; SRMR $=$ root mean square residual; $\mathrm{CFI}=\mathrm{comparative}$ fit index; TLI $=$ Tucker-Lewis index; $\Delta=$ incremental value. 
Procedure

The present study followed the ethical principles of the Declaration of Helsinki (World Medical Association, 1964) for medical research involving human subjects. After receiving informed consent, participants were notified of the purpose of the study and proceeded to answer the scale in their classroom.

\section{Data analysis}

Multivariate normality analyses (Mardia, 1970) were performed using the $\mathrm{R}$ software ( $\mathrm{R}$ Core Team, 2013). Absolute values of $>5$ and a $p$ $<.05$ were indicative of non-normality.

All confirmatory analyses were performed with Mplus 8.0 software (Muthén \& Muthén, 2017). Given the discrepancies in the underlying structure of the NSSS-S, we did not use the one-dimensional structure proposed by Štulhofer et al. (2011), instead, we tested two models: one-dimensional (Štulhofer et al., 2011) and bifactorial (Mark et al., 2014). To assess the fit of the model, two absolute fit indices were used: 1) the Satorra-Bentler scaled chi-square (S-B $\chi^{2} / d f$ ) and 2) the standardized root mean square residual (SRMR). Additionally, two comparative adjustment indices were used: The comparative fit index (CFI) and the Tucker-Lewis index (TLI); and a parsimonious adjustment index, the root mean square error of approximation (RMSEA). To consider that the model has a proper fit, values less than 2 indicate good fit and values between 2 and 3 indicate acceptable fit for the S-B $\chi^{2} / d f$ index (Schermelleh-Engel, Moosbrugger, \& Müller, 2003); for the SRMR index, values less than .05 are indicative of a good fit (Hooper, Coughlan, \& Mullen, 2008); for CFI and TLI, values $>.95$ are interpreted as a good fit (Hu \& Bentler, 1999); and for the RMSEA, an index between .05 and .08 is considered as a reasonable adjustment (Browne \& Cudeck, 1993).

The analysis of invariance by sex with MGCFA included the examination of the configural invariance, the metric invariance, the scalar invariance, and the residual or strict invariance. To evaluate the incremental models, the Cheung and Rensvold (2002) criteria were used: $\triangle$ RMSEA $\leq$ .015 and $\Delta \mathrm{CFI} \leq .01$.

To calculate the internal consistency of the scale, McDonald's (1999) coefficient omega ( $\omega)$ was used, which works with factor loads, which reduce the risk of overestimating reliability since it does not depend on the number of items and can be used in continuous variables. The values of $\omega$ can be interpreted as: unacceptable $(<.70)$, fair $(.70-.79)$, good $(.80-.89)$ and excellent $(\geq .90$; Cicchetti, 1994).

Finally, to obtain evidence of temporal stability, Pearson's correlation coefficients $(r)$ and intraclass correlation (ICC) were used. Values of $r$ can indicate: null correlation $(<.30)$, low correlation (.30 - .49), moderate correlation (.50 - .69), high correlation $(.70-.90)$ and very high correlation (> .90; Hinkle, Wiersma, \& Jurs, 2003). For the ICC, the values are classified as: low reliability $(<.5)$, moderate reliability $(.5-.74)$, good reliability (.75-.90) and excellent reliability (>.90; Portney \& Watkins, 2000).

\section{Results \\ Preliminary analysis}

Multivariate normality tests indicated that the data was not normally distributed (skewness 15.98, $p=1.00$; kurtosis 208.17, $p<.001$ ), for both men (skewness 27.17, $p=1.00$; kurtosis 
Table 3

Internal consistency and temporal stability of the NSSS-S by sex.

\begin{tabular}{|c|c|c|c|c|c|c|c|c|c|}
\hline \multirow[b]{2}{*}{$\begin{array}{l}\text { Scale and } \\
\text { sub-scales }\end{array}$} & \multicolumn{3}{|c|}{ Males } & \multicolumn{3}{|c|}{ Females } & \multicolumn{3}{|c|}{ Full sample } \\
\hline & $\begin{array}{c}r \\
(\mathrm{CI} \\
95 \%)\end{array}$ & $\begin{array}{c}\text { ICC } \\
(\mathrm{CI}, 95 \%)\end{array}$ & $\omega$ & $\begin{array}{r}r \\
(\mathrm{CI} \\
95 \%)\end{array}$ & $\begin{array}{c}\text { ICC } \\
(\mathrm{CI}, 95 \%)\end{array}$ & $\omega$ & $\begin{array}{c}r \\
(\mathrm{CI}, 95 \%)\end{array}$ & $\begin{array}{c}\text { ICC } \\
(\mathrm{CI}, 95 \%)\end{array}$ & $\omega$ \\
\hline Ego-Centered & $\begin{array}{c}.51 \\
(.04- \\
.82)\end{array}$ & $\begin{array}{c}.67 \\
(.38-.83)\end{array}$ & .90 & $\begin{array}{c}.82 \\
(.60-.92)\end{array}$ & $\begin{array}{c}.90 \\
(.81-.95)\end{array}$ & .89 & $\begin{array}{c}.71 \\
(.48-.84)\end{array}$ & $\begin{array}{c}.83 \\
(.73-.89)\end{array}$ & .89 \\
\hline $\begin{array}{l}\text { Partner- and } \\
\text { Sexual Activi- } \\
\text { ty-Centered }\end{array}$ & $\begin{array}{c}.70 \\
(.36- \\
.87)\end{array}$ & $\begin{array}{c}.82 \\
(.66-.91)\end{array}$ & .91 & $\begin{array}{c}.79 \\
(.33-.91)\end{array}$ & $\begin{array}{c}.88 \\
(.77-.94)\end{array}$ & .89 & $\begin{array}{c}.75 \\
(.54-.87)\end{array}$ & $\begin{array}{c}.85 \\
(.77-.91)\end{array}$ & .90 \\
\hline Full-scale & $\begin{array}{c}.65 \\
(.33-.86)\end{array}$ & $\begin{array}{c}.79 \\
(.60-.89)\end{array}$ & .95 & $\begin{array}{c}.82 \\
(.49-.92)\end{array}$ & $\begin{array}{c}.90 \\
(.80-.95)\end{array}$ & .94 & $\begin{array}{c}.74 \\
(.50-.87)\end{array}$ & $\begin{array}{c}.85 \\
(.77-.91)\end{array}$ & .94 \\
\hline
\end{tabular}

Note. Pearson and intraclass coefficients were significant $(p=.0001)$.

202.58, $p<.001$ ), and women (skewness 22.48, $p$ $=1.00$; kurtosis 206.85, $p<.001$ ). Therefore, subsequent analyses were performed using the robust maximum likelihood estimation (MLR) method.

\section{Confirmatory factor analysis}

The CFA was performed to evaluate the fit of two models: one-dimensional and bifactorial (F1 = items 1-6; F2 = items 7-12). As shown in Table 1, the two models have adequate fit indices, although Model 2 presents better fit indices. After inspecting the modification indices, we released covariance errors between items 11 and 12, thus, improving the fit. For this model, the item-total correlations ranged from .71 to .82 . The items loaded significantly in their respective factor $(p$ $<.0001$ ) and ranged from .69 to .83. Subsequent analyses were performed using the re-specified two-factor model $(\mathrm{F} 1=$ items $1-6 ; \mathrm{F} 2=$ items 7-12).
Invariance analysis by sex

We first evaluated the fit of the re-specified model for each group (men and women). As shown in Table 2, the fit was acceptable for women and good for men. For the configural invariance, the measure of model fit was good. Furthermore, the changes in CFI and RMSEA indicate that the NSSS-S is invariant for sex, therefore, the scale can be applied to men and women.

\section{Internal consistency}

The omega coefficient indicated that the 12 items of the NSSS-S show good internal consistency for the whole sample, for both men and women (Table 3).

\section{Temporal stability analysis}

A subsample of 76 participants answered 
the NSSS-S four weeks after the first application. Temporal stability analysis showed low Pearson and ICC correlations for men compared to women on the scale and its two subscales (Table 3).

\section{Sex comparisons}

Since the NSSS-S was invariant for sex, SS was compared in men and women. Results showed that men have higher global SS $(\mathrm{M}=$ 47.07, $\mathrm{SD}=8.50)$ than women $(\mathrm{M}=46.44$, SD $=9.51), t_{(401)}=.68, p=.50$. In addition, in the Ego-Centered subscale, men scored higher $(\mathrm{M}=$ $24.14, \mathrm{SD}=4.17)$ than women $(\mathrm{M}=23.58, \mathrm{SD}=$ $4.77), t_{(401)}=1.26, p=.21$. Finally, no differences were observed in the partner -and Sexual Activity-Centered subscale $t_{(401)}=.12, p=.90$, between men $(\mathrm{M}=22.93, \mathrm{SD}=4.72)$ and women $(\mathrm{M}=$ $22.86, \mathrm{SD}=5.15)$.

\section{Discussion}

The purpose of this study was to assess the incremental validity of the NSSS-S. To our knowledge, this is the first study to focus on this aspect of the scale. Therefore, after re-specifying the model, the invariance by sex was tested. The NSSS-S showed metric, scalar, and strict invariance. These findings indicate that the construct represented by the NSSS-S is the same for university men and women, and the scores and means of the NSSS-S can be compared between these groups.

Although there are various instruments to evaluate SS (González-Rivera et al., 2017; Hudson et al., 1981; Lawrance \& Byers, 1995; Meston
\& Trapnell, 2005; Pinney et al., 1987; Rust \& Golombok, 1986), the NSSS-S has a theoretical framework and allows evaluating personal SS as a couple, regardless of gender, sexual orientation or marital status. Furthermore, the scale can be used in non-clinical settings. However, studies have reported inconsistent results regarding the factor structure of the NSSS-S. Some authors have found that the scale is unifactorial (Hoy et al., 2019; Štulhofer et al., 2011), and others point out that it is bifactorial (Mark et al., 2014; Santos-Pechorro et al., 2016; Strizzi et al., 2016). Our results support the two-factor structure of NSSS-S.

Most previous studies have evaluated the internal consistency of the NSSS-S using the Cronbach's alpha coefficient. In this study, internal consistency was assessed using the McDonald's omega coefficient (1999), which allows a more precise estimation of the internal consistency of the items and reduces the effect of the number of the items included in the scale. Consistent with the findings of previous studies (Hoy et al., 2019; Mark et al., 2014; Santos-Pechorro et al., 2016; Strizzi et al., 2016; Štulhofer et al., 2011), our findings support the internal consistency of the NSSS-S and its subscales for both men and women. Furthermore, the scale has adequate temporal stability, which is also consistent with previous studies (Mark et al., 2014; Štulhofer et al., 2011).

In gender comparisons, our findings are consistent with previous studies (for a review, see Petersen \& Hyde, 2010), which indicate that $\mathrm{SS}$ is higher in men than in women. These results support the conclusions of Hyde (2005) about gender differences in sexuality. Also, each society has different criteria to value sexuality, being that men have greater sexual freedom as compared to women (Grindell, 2009).

Finally, the findings of this study indicate that the NSSS-S is a two-dimensional measure 
that allows evaluating SS in Spanish-speaking Latino adults. The scale has incremental validity, adequate internal consistency, and temporal stability.

\section{Limitations}

Despite the contribution of this study, we can highlight some limitations, for example, the sample was recruited from only two public universities, which could be unrepresentative of adults from other Spanish-speaking cities, so future studies could include samples representative of other Spanish-speaking regions and may even include older adults.

SS studies have mainly been focused on heterosexual people (Sánchez-Fuentes \& Sierra, 2015). Another limitation of this study was that it did not include a sample of participants with different sexual orientation, so this aspect should also be addressed in future studies with Hispanic-Latino populations.

In addition, future studies could assess the invariance of this scale, according to the body mass index and the marital status of the participants, which are variables associated with SS. Furthermore, in this study it was not possible to cross-validate the re-specified model using a new sample, which would represent another contribution to the incremental validity of the scale.

Finally, a further limitation of this study was that convergent and divergent validity of the scale were not evaluated.

\section{References}

Ahumada, S. G., Luttges, C. D., Molina, T. G., \& Torres, S.
G. (2014). Satisfacción sexual: Revisión de los factores individuales y de pareja relacionados [Sexual satisfaction: Review of related individual and partner factors]. Revista Hospital Clínico Universidad de Chile, 25(4), 278-284. Retrieved from https:// www.redclinica.cl/ActividadAcad\%C3\%A9mi$\mathrm{ca} /$ RevistaHCUCH/DespliegueRevHospClinUnivChile/042014/tabid/1175.aspx

Bancroft, J., Loftus, J., \& Long, J. S. (2003). Distress about sex: A national survey of women in heterosexual relationships. Archives of Sexual Behavior, 32(3), 193-208. Retrieved from https://www.springer.com/ journal/10508

Browne, M. W., \& Cudeck, R. (1993). Alternative ways of assessing model fit. In K. A. Bollen \& J. S. Long (Eds.), Testing structural equation models (pp. 136162). Thousand Oaks, CA: Sage Publications.

Carrobles, J. A., \& Sanz-Yaque, A. (1991). Terapia sexual [Sexual therapy]. España: Fundación Universidad Empresa.

Cheung, G. W., \& Rensvold, R. B. (2002). Evaluating goodness of fit indexes for testing measurement invariance. Structural Equation Modeling: A Multidisciplinary Journal, 9(2), 233-255. doi: 10.1207/ S15328007SEM0902 5

Cicchetti, D. V. (1994). Guidelines, criteria, and rules of thumb for evaluating normed and standardized assessment instruments in psychology. Psychological Assessment, 6(4), 284-290. doi: 10.1037/10403590.6.4.284

Domínguez-Lara, S. A., \& Merino-Soto, C. M. (2015). ¿Por qué es importante reportar los intervalos de confianza del coeficiente alfa de Cronbach? [Why is it important to report the confidence intervals of the Cronbach's alpha coefficient?]. Revista Latinoamericana de Ciencias Sociales, Niñez y Juventud, 13(2), 1326-1328. Retrieved from http://revistaumanizales. cinde.org.co/rlcsnj/index.php/Revista-Latinoameri- 
cana/index

González-Rivera, J. A., \& Hernández-Gato, I. (2019). Validación de una versión breve de la Escala de Satisfacción Sexual Subjetiva (ESSS-B) en Puerto Rico [Validation of a Short Version of the Subjective Sexual Satisfaction Scale (ESSS-B) in Puerto Rico]. Revista Evaluar, 19(2), 43-57. doi: 10.35670/1667-4545. v19.n2.25082

González-Rivera, J. A., Veray-Alicea, J., Santiago-Santos, D., Castro-Castro, S., \& Quiñones-Soto, R. (2017). Desarrollo y validación de una escala para medir satisfacción sexual subjetiva en adultos puertorriqueños [Development and validation of a scale to measure subjective sexual satisfaction in Puerto Rican adults]. Salud y Conducta Humana, 4(1), 52-63. Retrieved from http://rsych.com

Grindell, V. M. (2009). Sexual satisfaction in young adults: Are there gender and age differences using the crucible ${ }^{\circledR}$ sexual relationship inventory? (Publication No.3421101) [Doctoral dissertation, Alliant International University]. ProQuest Dissertations \& Theses Global.

Hinkle, D. E., Wiersma, W., \& Jurs, S. G. (2003). Applied statistics for the behavioral sciences ( $5^{\text {th }}$ ed.). Boston, MA: Houghton Mifflin.

Hooper, D., Coughlan, J., \& Mullen, M. R. (2008). Structural equation modelling: Guidelines for determining model fit. Electronic Journal of Business Research Methods, 6(1), 53-60. Retrieved from http:/www. ejbrm.com/main.html

Hoy, M., Strauß, B., Kröger, C., \& Brenk-Franz, K. (2019). Überprüfung der deutschen Kurzversion der "New Sexual Satisfaction Scale" (NSSS-SD) in einer repräsentativen stichprobe [Evaluation of the German short version of the "New Sexual Satisfaction Scale" (NSSS-SD) in a representative sample]. Psychotherapie, Psychosomatik, Medizinische Psychologie, 69(3-4), 129-135. doi: 10.1055/a-0620-0002
Hu, L-. T., \& Bentler, P. M. (1999). Cutoff criteria for fit indexes in covariance structure analysis: Conventional criteria versus new alternatives. Structural Equation Modeling: A Multidisciplinary Journal, 6(1), 1-55. doi: 10.1080/10705519909540118

Hudson, W. W., Harrison D. F., \& Crosscup, P. C. (1981). A short-form scale to measure sexual discord in dyadic relationships. Journal of Sex Research, 17(2), 157174. doi: 10.1080/00224498109551110

Hyde, J. S. (2005). The gender similarities hypothesis. American Psychologist, 60(6), 581-592. doi: 10.1037/0003-066X.60.6.581

Kalichman, S. C., Johnson, J. R., Adair, V., Rompa, D., Multhauf, K., \& Kelly, J. A. (1994). Sexual Sensation-Seeking: Scale development and predicting AIDS-risk behavior among homosexually active men. Journal of Personality Assessment, 62(3), 385397. doi: 10.1207/s15327752jpa6203_1

Lawrance, K., \& Byers, E. S. (1995). Sexual satisfaction in long-term heterosexual relationship: The interpersonal exchange model of satisfaction. Personal Relationship, 2(4), 267-285. Retrieved from https:// onlinelibrary.wiley.com/journal/14756811

Mardia, K. V. (1970). Measures of multivariate skewness and kurtosis with applications. Biometrika, 57(3), 519-530. doi: 10.1093/biomet/57.3.519

Mark, K. P., Herbenick, D., Fortenberry, J. D., Sanders, S., \& Reece, M. (2014). A psychometric comparison of three scales and a single-item measure to assess sexual satisfaction. The Journal of Sex Research, 51(2), 159-169. doi: 10.1080/00224499.2013.816261

McDonald, R. P. (1999). Test theory: A unified treatment. New York, NY: Lawrence Erlbaum Associates. doi: $10.4324 / 9781410601087$

Meston, C., \& Trapnell, P. (2005). Development and validation of a five-factor sexual satisfaction and distress scale for women: The Sexual Satisfaction Scale for 
Women (SSS-W). The Journal of Sexual Medicine, 2(1), 66-81. doi: 10.1111/j.1743-6109.2005.20107.x

Moral de la Rubia, J. (2018). Validación de la Escala de Búsqueda de Sensaciones Sexuales en mexicanos casados o cohabitantes [Validation of the Sexual Sensation Seeking Scale among married or cohabiting Mexicans]. Revista Evaluar, 18(3), 49-72. doi: 10.35670/1667-4545.v18.n3.22224

Muthén, L. K., \& Muthén, B. O. (2017). Mplus (8.0). [Computer software]. Retrieved from https://www. statmodel.com

Petersen, J. L., \& Hyde, J. S. (2010). A meta-analytic review of research on gender differences in sexuality, 1993-2007. Psychological Bulletin, 136(1), 21-38. doi: $10.1037 / \mathrm{a} 0017504$

Pinney, E. M., Gerrard, M., \& Denney, N. W. (1987). The Pinney Sexual Satisfaction Inventory. The Journal of Sex Research, 23(2), 233-251. doi: 10.1080/00224498709551359

Portney, L. G., \& Watkins, M. P. (2000). Foundations of clinical research: Applications to practice ( $\left.2^{\text {nd }} e d.\right)$. Upper Saddle River, NJ: Prentice Hall.

R Core Team. (2013). $R$ : A language and environment for statistical computing. R Foundation for Statistical Computing, Vienna, Austria. Retrieved from http:// www.R-project.org

Rust, J., \& Golombok, S. (1986). The GRISS: A psychometric instrument for the assessment of sexual dysfunction. Archives of Sexual Behavior, 15(2), 157165. doi: 10.1007/BF01542223

Sánchez-Fuentes, M. M., Santos-Iglesias, P., \& Sierra, J. C. (2014). A systematic review of sexual satisfaction. International Journal of Clinical and Health Psychology, 14(1), 67-75. doi: 10.1016/S16972600(14)70038-9

Sánchez-Fuentes, M. M., \& Sierra, J. C. (2015). Sexual sat- isfaction in a heterosexual and homosexual Spanish sample: The role of socio-demographic characteristics, health indicators, and relational factors. Sexual and Relationship Therapy, 30(2), 226-242. doi: 10.1080/14681994.2014.978275

Santos-Pechorro, P., Moneiro-Pascoal, P., Neves-Jesus, S., Almeida, A. I., Soares-Figueiredo, C., \& Vieira, R. X. (2016). Propriedades psicométricas da versão portuguesa da Nova Escala de Satisfação Sexual-versão curta [Psychometric properties of the Portuguese version of the New Sexual Satisfaction Scale-Short form]. Revista Internacional de Andrología, 14(3), 94-100. doi: 10.1016/j.androl.2016.04.006

Schermelleh-Engel, K., Moosbrugger, H., \& Müller, H. (2003). Evaluating the fit of structural equation models: Tests of significance and descriptive goodnessof-fit measures. Methods of Psychological Research Online, 8(2), 23-74. Retrieved from https://www. dgps.de/fachgruppen/methoden/mpr-online

Strizzi, J., Fernández-Agis, I., Alarcón-Rodríguez, R., \& Parrón-Carreño, T. (2016). Adaptation of the New Sexual Satisfaction Scale-Short Form into Spanish. Journal of Sex \& Marital Therapy, 42(7), 579-588. doi: 10.1080/0092623X.2015.1113580

Štulhofer, A., Buško, V., \& Brouillard, P. (2010). Development and bicultural validation of the New Sexual Satisfaction Scale. The Journal of Sex Research, 47(4), 257-268. doi: 10.1080/00224490903100561

Štulhofer, A., Buško, V., \& Brouillard, P. (2011). The New Sexual Satisfaction Scale and its short form. In T. D. Fisher, C. M. Davis, W. L. Yarber \& S. L. Davis (Eds.), Handbook of Sexuality-Related Measures (3 ${ }^{\text {rd }}$ ed., pp. 530-533). doi: 10.4324/9781315881089

World Medical Association. (1964). Declaration of Helsin$k i$. Retrieved from https://www.wma.net 